\title{
Rapid prototyping of a complex model for the manufacture of plaster molds for slip casting ceramic
}

\section{(Prototipagem rápida de um modelo complexo para fabricação de moldes de gesso para barbotina cerâmica)}

\author{
D. P. C. Velazco', E. F. Sancet ${ }^{1}$, F. Urbaneja ${ }^{1}$, M. Piccico ${ }^{2}$, M. F. Serra ${ }^{2}$, \\ M. F. Acebedo ${ }^{2}$, G. Suárez ${ }^{2}$, N. M. Rendtorff ${ }^{2 *}$ \\ ${ }^{1}$ Universidad Nacional de Lanús, 29 de Setiembre 3901 CP.B1826GLC, Remedios de Escalada, Argentina \\ dindustrial@unla.edu.ar \\ ${ }^{2}$ CETMIC, Centro de Tecnología de Recursos Minerales y Cerámica (CIC-CONICET La Plata), Cno. Centenario \\ and 506, M. B. Gonnet, Buenos Aires, Argentina \\ *rendtorff@cetmic.unlp.edu.ar
}

\begin{abstract}
Computer assisted designing (CAD) is well known for several decades and employed for ceramic manufacturing almost since the beginning, but usually employed in the first part of the projectual ideation processes, neither in the prototyping nor in the manufacturing stages. The rapid prototyping machines, also known as 3D printers, have the capacity to produce in a few hours real pieces using plastic materials of high resistance, with great precision and similarity with respect to the original, based on unprecedented digital models produced by means of modeling with specific design software or from the digitalization of existing parts using the so-called 3D scanners. The main objective of the work is to develop the methodology used in the entire process of building a part in ceramics from the interrelationship between traditional techniques and new technologies for the manufacture of prototypes. And to take advantage of the benefits that allow us this new reproduction technology. The experience was based on the generation of a complex piece, in digital format, which served as the model. A regular $15 \mathrm{~cm}$ icosahedron presented features complex enough not to advise the production of the model by means of the traditional techniques of ceramics (manual or mechanical). From this digital model, a plaster mold was made in the traditional way in order to slip cast clay based slurries, freely dried in air and fired and glazed in the traditional way. This experience has shown the working hypothesis and opens up the possibility of new lines of work to academic and technological levels that will be explored in the near future. This technology provides a wide range of options to address the formal aspect of a part to be performed for the field of design, architecture, industrial design, the traditional pottery, ceramic art, etc., which allow you to amplify the formal possibilities, save time and therefore costs when drafting the necessary and appropriate matrixes to each requirement.
\end{abstract}

Keywords: digital modeling, 3D printing, traditional ceramics.

\section{Resumo}

Projeto assistido por computador (CAD) é bem conhecido por várias décadas e empregado na fabricação cerâmica desde o início, mas usualmente empregado na primeira parte dos processos na concepção do projeto, nem na prototipagem, nem nas fases de fabricação. As máquinas de prototipagem rápida, também conhecidas como impressoras $3 D$ têm a capacidade de produzir, em poucas horas, peças utilizando materiais plásticos de alta resistência, com grande precisão e similaridade com relação ao original, com base em modelos digitais inéditos produzidos por meio de modelagem com softwares de projeto especifico ou a partir da digitalização das peças existentes, utilizando os chamados scanners $3 D$. O principal objetivo deste trabalho é desenvolver a metodologia utilizada em todo o processo de construção de uma parte em cerâmica da inter-relação entre as técnicas tradicionais e novas tecnologias para a fabricação de protótipos. E para aproveitar os benefícios que nos permitem esta nova tecnologia de reprodução. A experiência baseou-se na geração de uma peça complexa, em formato digital, que serviu como modelo. Um icosaedro regular de $15 \mathrm{~cm}$, complexo o suficiente para não sugerir a produção do modelo por meio das técnicas tradicionais cerâmicas (manual ou mecânica). A partir deste modelo digital, um molde de gesso feito na maneira tradicional para colagem por barbotina de massas à base de argila, secagem livre ao ar, queimada e esmaltada de maneira tradicional. Esta experiência mostrou a hipótese de trabalho e abre a possibilidade de novas linhas de trabalho a níveis acadêmicos e tecnológicos que serão explorados em um futuro próximo. Esta tecnologia oferece uma grande variedade de opções para lidar com o aspecto formal de uma peça a ser executada no campo do projeto, arquitetura, projeto industrial, a cerâmica tradicional, a arte cerâmica, etc., que permitem ampliar as possibilidades formais, economizar tempo e, portanto, os custos na elaboração das matrizes necessárias e adequadas para cada exigência.

Palavras-chave: modelagem digital, impressão 3D, cerâmicas tradicionais. 


\section{INTRODUCTION}

Computer assisted designing (CAD) is well known for several decades and employed for ceramic manufacturing almost since the beginning, but usually employed in the first part of the projectual ideation processes, neither in the prototyping nor in the manufacturing. In other words, the CAD designs generally are left in paper and afterward manually (handcrafted) modeled in to the final shape, or for the most this was carried out mechanically. Models are made of different modeling (and prototyping) materials, like wood, plaster, metal, resin, silicon etc.

A new designing - prototyping - manufacturing (DPM) methodology for traditional ceramic shapes using rapid prototyping technologies is shown in this article, both for industrial or artistic objectives.

The commonly called 3D printers have the capability of producing parts in a few hours using volumetric real plastic materials of high resistance, which makes them long lasting parts, manipulated and therefore suitable for use as molding arrays (matrix), facilitating their reproduction in different materials [1-4].

The FDM (Fused Deposition Modeling) stands out within these technologies because of its cost and versatility. It consists in a heated header through which pass two independent filaments of a colored polymer, which are extruded on a base reproducing, in layers of a few tenths of a millimeter, the morphology sent from the computer. This technology allows access to the production of high complexity shapes, with a wide range of possibilities, pretending to highlight in this case those referring to the digital-material production of functional models and molds for mass-production of ceramic pieces [514]. Much effort is being carried out with these technologies in ceramic materials especially in biomedical applications [10-14]. However this kind of digital technologies present an important technological potential in other ceramic applications in different stages, both in the ideation and prototyping and in some cases if the complexity and specificity is worth enough in manufacturing of ceramic parts. This article focuses in this kind of application.

Prototyping machines have the benefit of reproducing with great precision and similarity with respect to the original. The precision claimed by machine suppliers is about a tenth of the filament thickness. The original part, the matrix, can be done based on unprecedented digital models that are produced by means of modeling with specific design software, thus generating a unique piece, the original, based on the specific needs of the object to be built. It can also reproduce parts or models from the digitalization of other existing parts or models using the so called 3D scanners [1-4]. This technology provides a wide range of options to address the formal aspect of a part to be built for the fields of design, architecture, industrial design, art, etc., that allow to amplify the possibilities in designing the exclusive necessary and appropriate matrixes to each requirement. This technology is also valued by saving the costs in the production of arrays of complex shapes in the elaboration of molding for traditional ceramics.
The main objective of the work is to develop the methodology used in the entire process of building a part in ceramics from the interrelationship between traditional techniques and new technologies for the manufacture of prototypes. And to take advantage of the benefits that allow us this new reproduction technology; significantly speeding up the production times, economizing costs, developing almost unimaginable ways in the execution of a traditional manual or mechanical process and above all, introducing to the community of ceramics a technology that, although complex, does not cease to be accessible and very versatile for the requirements of the sector.

\section{EXPERIMENTAL PROCEDURE}

The experience was based on the elaboration of a model geometric shape (a regular icosahedron); that in digital format presented features complex enough not to advise the production of the model by means of the traditional techniques of ceramics (manual or mechanical). This complex ceramic model shape was chosen in order to understand de intrinsic characteristics of this DPM methodology. This experience represent the application of this cutting edge ideation-fabrication technology applied to traditional ceramic industries like clay based ceramics.

First, the model was digitally constructed in CAD software. Although the shape is a solid, for the subsequent molding only a strength enough core is needed. Previous experience showed that $2 \mathrm{~mm}$ thickness present enough mechanical strength for constructing the printed shape.

The model of the icosahedron (15 cm height) was printed with the 3D Dimension BST 768 printer, of Stratasys company, which operates from the extrusion of two plastic filaments of ABS (Acrylonitrile Butadiene Styrene) that are deposited in $0.25 \mathrm{~mm}$ layers, each performing the will subsequently act as the of model material and support material respectively. The support must be removed manually from the finished model to obtain the final part. The mechanical strength of the employed filament cannot be change; in order to make strong model walls the thickness can be increased. In this case the wall thickness was $2 \mathrm{~mm}$; this was achieved by overlapping several filament layers $(0.25 \mathrm{~mm}$ each). As mentioned the precision is below $0.05 \mathrm{~mm}$, the strength showed to be enough. The regular icosahedron made of plastic with the 3D printer was used as a model for its reproduction in ceramics. There was a two parts plaster mold as it is usually used in traditional pottery. The casting was carried out with white clay slurry, with 20 min to wait for the formation of the layer by capillary absorption. Then each icosahedron of clay was tweaked, dried at room temperature and subsequently fired in an electric kiln in an oxidizing atmosphere at $1040{ }^{\circ} \mathrm{C}$ for one hour, at normal temperature firing the employed commercial calcareous clay, extensively described in $[15,16]$. Subsequently for finishing the process a ceramic glaze (commercial) was applied and fired at the same temperature. 


\section{RESULTS AND DISCUSSION}

Fig. 1 shows images of the digital modeling process of the body chosen: The icosahedron. Due to operational issues the array was separated in two halves, this kind of operative decisions are usually carried out in FDM printing, and are strongly bonded to the size, shape, symmetry of the digital model. It was manufactured with a $2 \mathrm{~mm}$ thickness; and two buttons were incorporated as seen in Fig. 1. After the checks and the renders (Fig. 2) the pattern was inserted in the printing software (Fig. 3). Then the printer is displayed and the printed patterns are obtained (Fig. 4); in red the model, in white the supports needed to be able to print the model correctly.

The model was then used in the manufacture of ceramic parts by a traditional route for cast of slip limestone ceramics in plaster molds.

The various stages of the process (Figs. 5-7), its characteristics and the processed products will be shown. This experience has shown the working hypothesis and
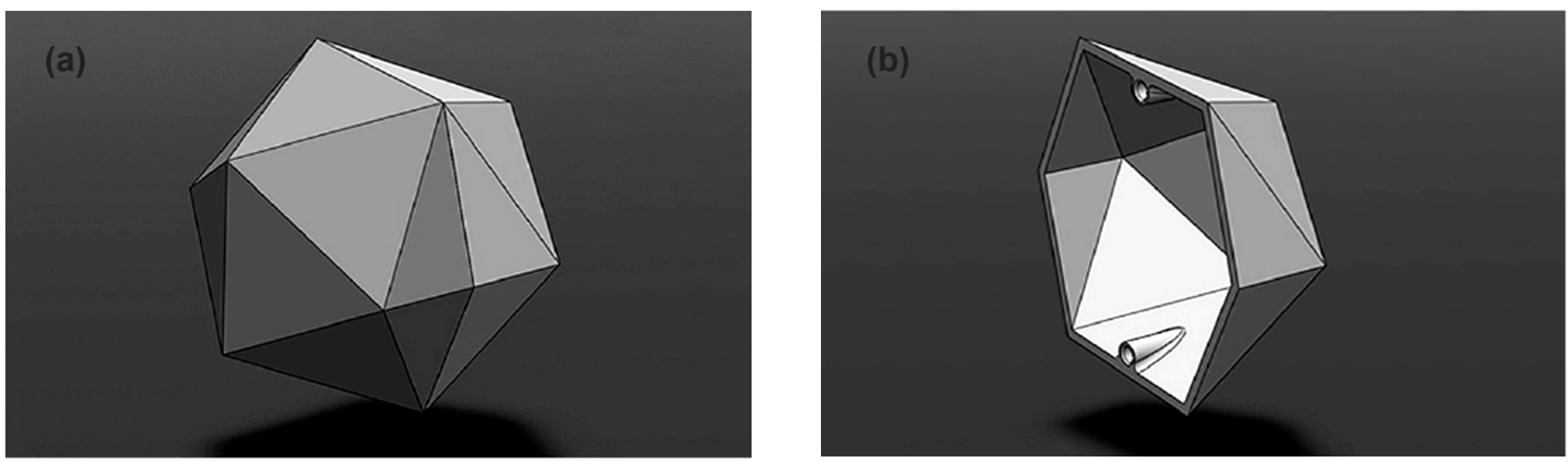

Figure 1: Initial 3D modeling of the icosahedron - Assembled and open. [Figura 1: Modelagem inicial 3D do icosaedro - montado e aberto.]
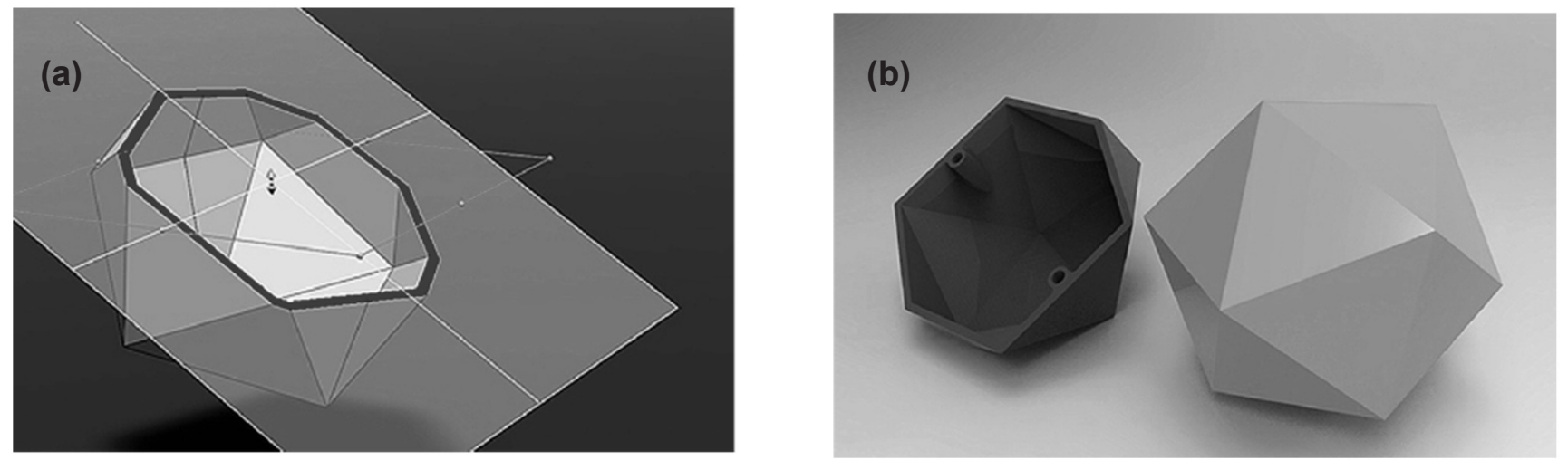

Figure 2: Checks for correct assemble with cuts and renders to verify how it would be.

[Figura 2: Testes de montagem correta com corte e apresentação de como seria.]
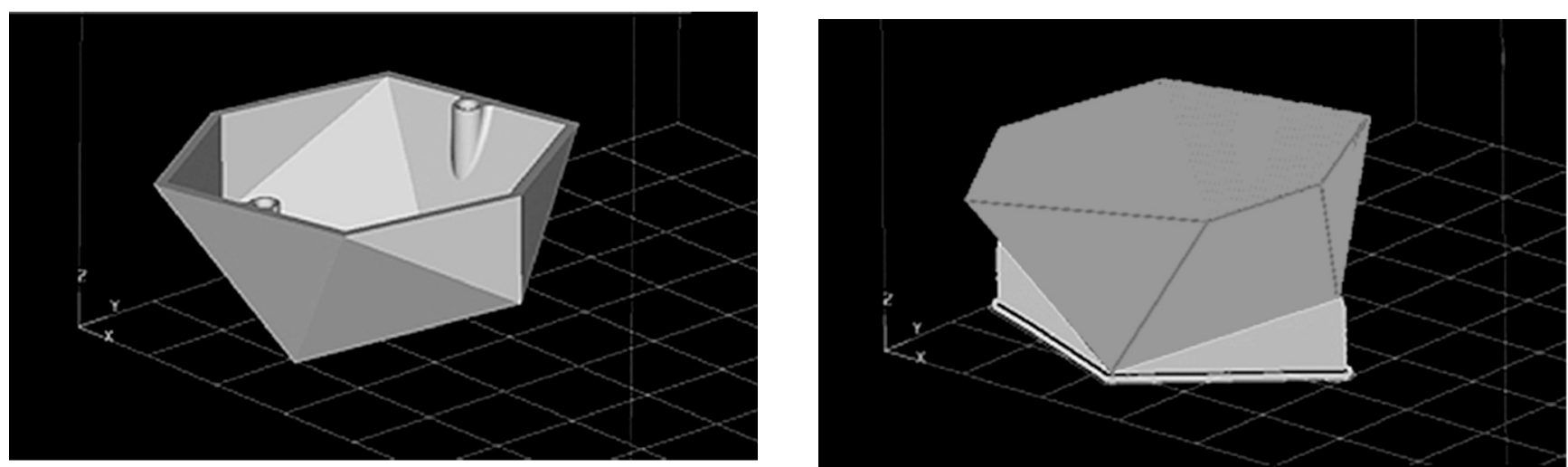

Figure 3: Insertion of the icosahedron in the printing software and calibration of the icosahedron in the printing software and support calculations.

[Figura 3: Inserção do icosaedro no software de impressão e calibração do icosaedro no software de impressão e cálculos suporte.] 

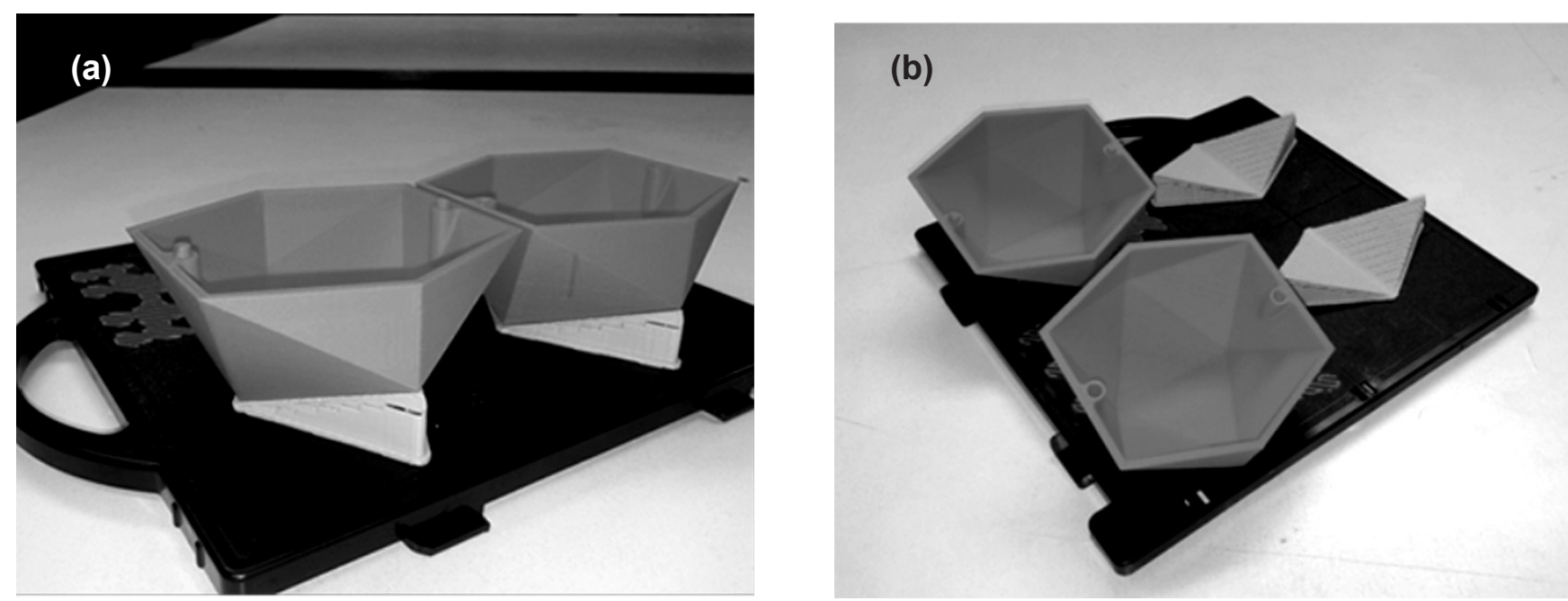

Figure 4: Base withdrawal (white) and parts (top) ready to be removed from the bracket and separate parts of the mounting brackets (black) and loose brackets.

[Figura 4: Extração da base (branco) e peças (acima) prontas para ser removidas do suporte e partes separadas dos suportes de montagem (preto) e suportes soltos.]
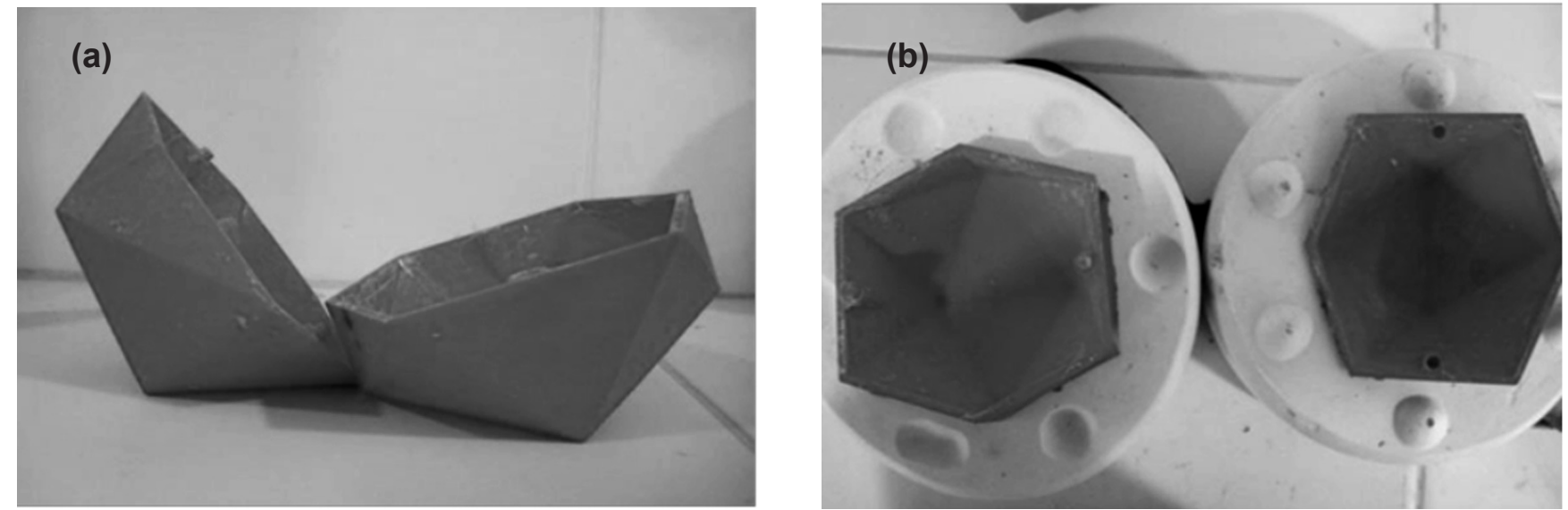

Figure 5: Plastic parts that make up the regular icosahedron made with the 3D printer. Plaster mold of each section to form the icosahedron, for its reproduction on clay.

[Figura 5: Peças de plástico que compõem o icosaedro regular feito com a impressora 3D. Molde de gesso de cada seção para formar o icosaedro, para sua reprodução em argila.]
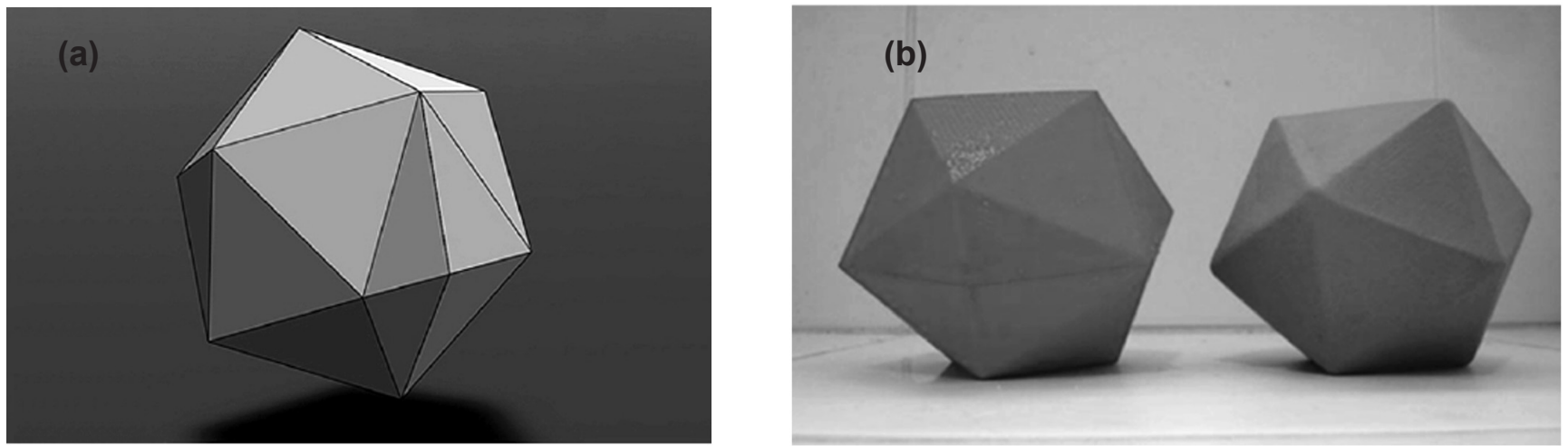

Figure 6: Comparison of the original part (digital) of the printed polymer made with the 3D printer (FDM) and clay made copy. [Figura 6: Comparação da peça original (digital) de polímero impresso feito com a impressora 3D (FDM) e cópia feita de argila.]

opens up the possibility of new lines of work at academic and technological levels that will be explored in the near future.

A disadvantage observed is the resolution of the printer which is approximately $0.3 \mathrm{~mm}$ and leaves marks on the supposedly flat surfaces; this problem can be saved through a later finishing with resin or painting of the printed patterns. In the present experience no further finishing processes was 


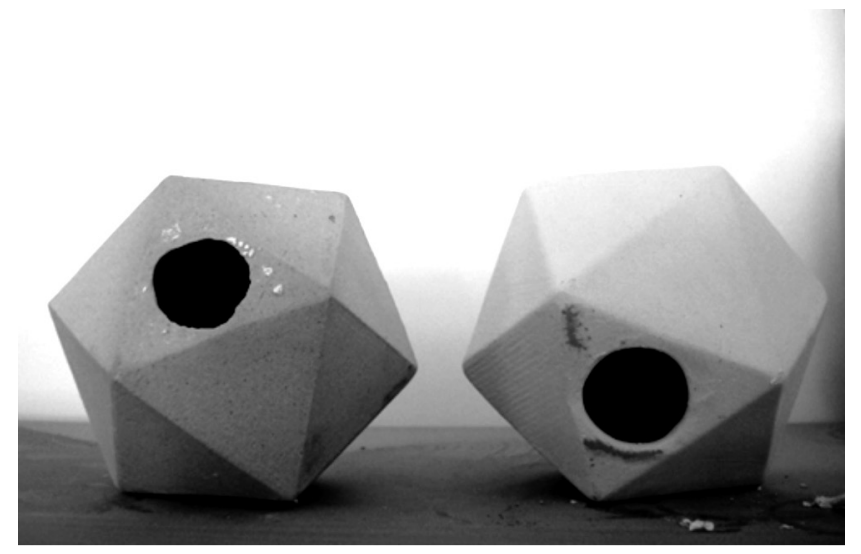

Figure 7: Biscuit fired ceramic icosahedrons obtained by the presented processing route.

[Figura 7: Icosaedros cerâmicos de biscuit queimados obtidos pela rota do processamento apresentado.]

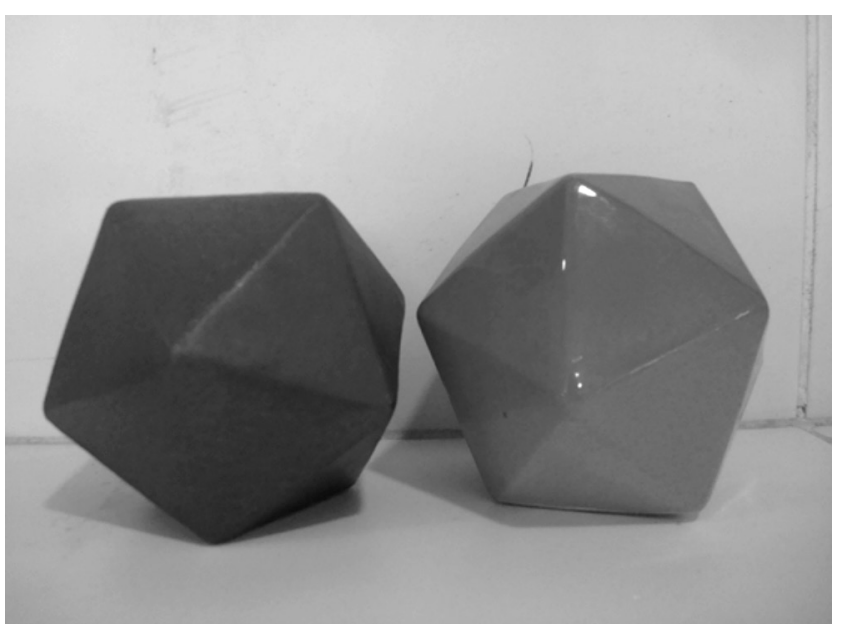

Figure 8: Glazed ceramic icosahedrons obtained by the presented processing route.

[Figura 8: Icosaedros de cerâmica vidrada obtidos pela rota de processamento apresentada.]

carried out to the 3D printed model, as mentioned it presents the extrusion pattern $(0.25 \mathrm{~mm}$ overlapped extruded cylinders), however the resulting plaster mold did not presented an important pattern. A soft sand paper treatment (mesh 500) was performed on the plaster mold surface. The resulting slip casted icosahedron did not present any vestige of the 3D printing overlapped cylindrical pattern. Sand paper was also used to polish the dried icosahedrons, before biscuit firing. In industrial or semi industrial ceramic manufacturing a sponge finishing is not abnormal. In the present experience it was, in some cases, carried out; this treatment was deleterious for the edge definition, as in traditional manufacture. The planarity of the icosahedron sides was adequate and similar to the one find when not 3D printed models are employed for the molds fabrication. No important deformation was observed, probably because the employed ceramic body $[15,16]$ do not present important glassy phase at the employed firing temperature $\left(1040^{\circ} \mathrm{C}\right)$. As expected, the slip casting processes did not defer from the traditional one the final dimension accuracy was within the expected range for the employed ceramic clay.

Fig. 8 shows the final glazed icosahedrons. The affordable geometries by the proposed technology are wider than wider than traditional modeling techniques, moreover in some cases impossible for forming models by the traditional way. The short experience has allowed experiencing the possibilities of a new path for the manufacture of parts and traditional materials. It can be used in parts of tableware, decoration ceramics, electric ceramics, sanitary ceramics and red ceramics (bricks, tiles), jewelry, manufacture of refractories by cast or vibrocast, etc.

It can also be used for die casting manufacturing of glass by thermo fusion or casting, or casting of metals, routes in which pottery is the media on which the matrix forms.

The limited size is within the disadvantages, the printer size determines the maximum size of each part, for this printer the maximum size is $300 \times 250 \times 20 \mathrm{~mm}^{3}$ but this can be saved by performing bigger models though the addition of several 3D printed shapes.

\section{CONCLUSIONS}

CAD is well known for several decades and employed for ceramic manufacturing almost since the beginning, but usually employed in the first part of the projectual ideation processes, neither in the prototyping nor in the manufacturing. A new designing - prototyping manufacturing (DPM) methodology for traditional ceramic shapes was experienced. This represent a cost reduction by accelerating the production times, improving reproducibility, symmetry, repetitive shapes and making easier geometrical shapes as well. This methodology reduces the prototype and model corrections and storage. Also presents the advantage and the novelty of being able to develop almost unimaginable shapes when implementing a traditional manual or mechanical process and above all, introducing to the community of the ceramics a technology that, although complex, does not cease to be affordable and very versatile for the requirements of the sector. Different characteristics of this MPD methodology were asses and discussed, not big difficulties were found beside size limitations and the presence of a minor roughness inherent to the cylindrical extrusion of the 3D printer, which was corrected with sand paper. This technology provides a wide range of options to address the formal aspect of a part to be performed for the field of design, architecture, industrial design, the traditional pottery, ceramic art, etc., which allow you to amplify the formal possibilities, save time and therefore costs when drafting the necessary and appropriate matrixes to each requirement.

\section{REFERENCES}

[1] L. Wood, "Rapid Automated Prototyping: An Introduction”, Industrial Press (1993) ISBN 0-8311-3047-4. [2] L. Binstock, "Rapid Prototyping System: Fast Track 
to Product Realization", Soc. Manufacturing Eng. (1994) ISBN 0-87263-454-X.

[3] P. Jacobs, "Rapid Prototyping \& Manufacturing", Soc. Manufacturing Eng. (1992) MI 48121-0930.

[4] C. Barnatt, "3D Printing: The Next Industrial Revolution", explainingthefuture.com (2013) ISBN 978-1-484-181768.

[5] M. J. Edirisinghe, "Solid freeform fabrication methods for engineering ceramics", Brit. Ceram. Trans. 97, 6 (1998) 283-286.

[6] J. G. Heinrich, "New developments in the Solid Freeform Fabrication of ceramic components", IFC Ceramic Forum Int. 76, 5 (1999) 29-35.

[7] J. W. Halloran, "Freeform fabrications of ceramics", Brit. Ceram. Trans. 98, 6 (1999) 299-303.

[8] H. Seitz, W. Rieder, S. Irsen, B. Leukers, C. Tille, "Three-dimensional printing of porous ceramic scaffolds for bone tissue engineering”, J. Biomed. Mater. Res. Part B: Appl. Biomater. 74, 2 (2005) 782-788.

[9] C. R. Meira, J. De Carvalho, B. M. Purquerio, C. A. Fortulan, "Development of gypsum powder and binder for 3D print rapid prototyping" Ceramica 59, 351 (2013) 401408.

[10] A. Butscher, M. Bohner, S. Hofmann, L. Gauckler, R. Müller, "Structural and material approaches to bone tissue engineering in powder-based three-dimensional printing",
Acta Biomater. 7, 3 (2011) 907-920.

[11] C. E. Wilson, J. D. De Bruijn, C. A. Van Blitterswijk, A. J. Verbout, W. J. A. Dhert, "Design and fabrication of standardized hydroxyapatite scaffolds with a defined macro-architecture by rapid prototyping for bone-tissueengineering research", J. Biomed. Mater. Res. - Part A 68, 1 (2004) 123-132.

[12] P. H. Warnke, H. Seitz, F. Warnke, S. T. Becker, S. Sivananthan, E. Sherry, Q. Liu, J. Wiltfang, T. Douglas, "Ceramic scaffolds produced by computer-assisted 3D printing and sintering: Characterization and biocompatibility investigations", J. Biomed. Mater. Res. - Part B Appl. Biomater. 93, 1 (2010) 212-217.

[13] H. Seitz, W. Rieder, S. Irsen, B. Leukers, C. Tille, "Three-dimensional printing of porous ceramic scaffolds for bone tissue engineering", J. Biomed. Mater. Res. - Part B Appl. Biomater. 74, 2 (2005) 782-788.

[14] M. F. Serra, M. S. Conconi, G. Suarez, E. F. Agietti, N. M. Rendtorff, "Firing transformations of an argentinean calcareous commercial clay", Ceramica 59, 350 (2013) 254261.

[15] M. F. Serra, M. F. Acebedo, M. S. Conconi, G. Suarez, E. F. Aglietti, N. M. Rendtorff, "Thermal evolution of the mechanical properties of calcareous earthenware", Ceram. Int. 40, 1B (2014) 1709-1716.

(Rec. 15/01/2014, Rev. 24/03/2014, Ac. 29/05/2014) 